\title{
Bacterial community dynamics in horizontal flow constructed wetlands with different plants for high salinity industrial wastewater polishing
}

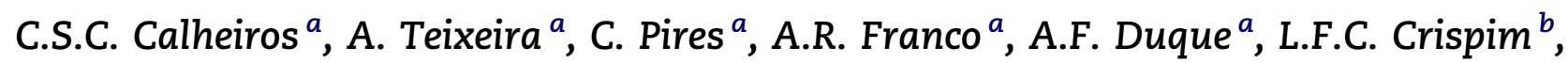 \\ S.C. Moura ${ }^{a}$, P.M.L. Castro ${ }^{a, *}$ \\ ${ }^{a}$ CBQF/Escola Superior de Biotecnologia, Universidade Católica Portuguesa, Rua Dr. António Bernardino de Almeida, 4200-072 Porto, \\ Portugal \\ ${ }^{\mathrm{b}}$ CTIC - Centro Tecnológico das Indústrias do Couro, Apartado 158 - São Pedro, 2384-909 Alcanena, Portugal
}

\author{
Keywords: \\ Bacterial communities \\ Constructed wetlands \\ Tannery wastewater \\ Arundo donax \\ Sarcocornia \\ Salinity
}

\begin{abstract}
A B S T R A C T
This study is focused on the diversity of bacterial communities from two series of horizontal subsurface flow constructed wetlands (CW) polishing high salinity tannery wastewater. Each series was planted with Arundo donax or Sarcocornia sp. in a substrate composed by expanded clay and sand. Chemical and biochemical oxygen demand removal efficiencies were similar in each series, varying between 58 and 67\% (inlet COD $218 \pm 28 \mathrm{mg} \mathrm{L}^{-1}$ ) and 60 and $77 \%$ (inlet BOD $_{5} 37 \pm 6 \mathrm{mg} \mathrm{L}^{-1}$ ), respectively. High numbers of culturable bacteria were obtained from substrate and root samples $-5.75 \times 10^{6}-3.95 \times 10^{8} \mathrm{CFU} \mathrm{g}^{-1}$ recovered on marine agar and $1.72 \times 10^{7}-8.46 \times 10^{8} \mathrm{CFU} \mathrm{g}{ }^{-1}$ on nutrient agar. Fifty bacterial isolates were retrieved from the $\mathrm{CW}$, related phylogenetically to Firmicutes, Actinobacteria, Bacteroidetes, $\alpha$-, $\beta$-, and $\gamma$-Proteobacteria. Changes in the bacterial communities, from roots and substrate of each series, related to the plant species, hydraulic loading rates and along CW operation were examined using denaturating gradient gel electrophoresis (DGGE). The clustering analysis suggested that a diverse and distinct bacterial community inhabits each series, which was related to the type of plant present in each CW.
\end{abstract}

\section{Introduction}

In the tanning industry hides and skins are typically traded in the salted state. Salt acts by inhibiting the growth and activity of bacteria through lowering the moisture content in rawstock. The quantity of salt (sodium chloride) applied depends largely on the storage time required for the leather. About $60 \%$ of total tannery chloride derives from salt used for curing purposes, which is then released in the soaking effluents. The remaining originates through the pickling and to some extent from tanning and dyeing processes. The typical untreated industrial wastewater is characterized by high chemical and biological oxygen demand and high salt content (EC., 2003). End-of-pipe water treatment represents the last but not the least important mitigation strategy. Significant technological advancements have been made in order to counteract frequent problems occurring in industrial scenarios, such as working over capacity due to poor design or due to increases in production. In these cases constructed wetlands (CW) can be used to improve the performance of an existing biological stage or to displace secondary or tertiary treatment (Daniels, 2007).

\footnotetext{
* Corresponding author. Tel.: +351 22 5580059; fax: +351 225090351.

E-mail address: plcastro@esb.ucp.pt (P.M.L. Castro).

0043-1354/\$ - see front matter (c) 2010 Elsevier Ltd. All rights reserved. doi:10.1016/j.watres.2010.07.017
} 
Treatment of tannery wastewater in CW has been reported recently (Calheiros et al., 2007, 2009b; Daniels, 2008). Plants have an effect on water quality that partially results from their effect on bacterial assemblages (Collins et al., 2004). In CW systems microorganisms have the main role in the removal of pollutants (Stottmeister et al., 2003; Faulwetter et al., 2009). It has been reported that reed beds are resilient to shock loadings, feeding suspension and to climate variations (Calheiros et al., 2007; Daniels, 2007). They also have performed well when subject to effluents with high salinity contents, up to 11,500 $\mathrm{mg} \mathrm{L}^{-1}$ in total dissolved solids (TDS) (Daniels, 2008). Klomjek and Nitisoravut (2005) also reported reduction on biochemical oxygen demand, $\mathrm{NH}_{3}-\mathrm{N}$ and total phosphorus in a CW under saline conditions (14-16 $\left.\mathrm{mS} \mathrm{cm}^{-1}\right)$. More recently, the study of Kaseva and Mbuligwe (2010) demonstrated that CW can be used as an option for improving the quality of tannery effluents, especially in the removal of chromium, with TDS levels around 10,000 $\mathrm{mg} \mathrm{L}^{-1}$.

The presence of plants in CW enhances microbial diversity and activity and, additionally, the plant species root morphology and development seems to be a key factor influencing microbial-plant interaction (Gagnon et al., 2007). Vymazal et al. (2001) also reported different microbial density accordingly to the plant species used in CW. Previous work on different types of CW provided us with an overview on microbial communities and factors affecting microbial activity on such systems (Faulwetter et al., 2009; Truu et al., 2009), but with no reference to the influence of high salinity content in such communities, a common scenario in the tannery industry. The work by Lefebvre et al. (2006) constitutes an attempt to describe the microbial communities involved in the aerobic and anaerobic treatment of hypersaline tannery wastewater.

In this study, the dynamics of microbial communities occurring within two CW series, planted with different species, treating high salinity content tannery wastewater was assessed. Bacterial enumeration and isolation and denaturating gradient gel electrophoresis (DGGE) analysis of $16 \mathrm{~S}$ rRNA gene were used for this purpose.

\section{Material and methods}

\subsection{Systems design and analytical methodology}

Two horizontal subsurface flow CW (area: $72 \mathrm{~m}^{2}$ ) were set up after a conventional tannery wastewater treatment (Fig. 1), for polishing purposes. Each series comprehended three compartments; the series planted with Arundo donax is designated as CWA (compartmented in: CWA1, CWA2 and CWA3) and series planted with Sarcocornia sp. is designated as CWS (compartmented in: CWS1, CWS2 and CWS3). The CW substratum comprised equal parts of Filtralite ${ }^{\circledR}$ NR 3-8 (FNR), with particle size ranging from 3 to $8 \mathrm{~mm}$, and washed sand, with particle size ranging from 0.5 to $1.0 \mathrm{~mm}$, up to a height of $35 \mathrm{~cm}$. Operation of the system was followed for one year, with the first two months considered as an acclimation period, when it was first fed with water and then with $50 \%$ diluted wastewater. During the following 180 days the system was subject to a flow of $4 \mathrm{~m}^{3} / \mathrm{d}$ and, then, during the

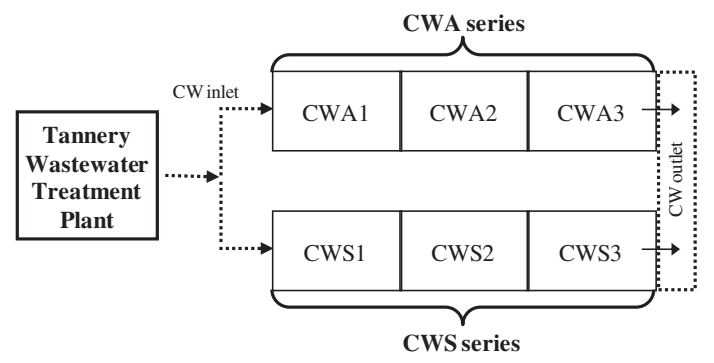

Fig. 1 - Schematic representation of the constructed wetlands (CW) series. CWA: CW series planted with Arundo donax (compartments: CWA1, CWA2 and CWA3) and CWS: CW with Sarcocornia sp. (compartments: CWS1, cWS2 and CWS3).

subsequent 125 days, to a flow of $10 \mathrm{~m}^{3} / \mathrm{d}$. When the system operated with a $10 \mathrm{~m}^{3} / \mathrm{d}$ flow the area was reduced to $48 \mathrm{~m}^{2}$ due to a sludge spill in the first unit of each series, which rendered it inadequate for continuing in operation.

Wastewater samples were collected from the inlet and outlet of both CW series, simultaneously with substrate and root samples for microbial analysis (four sampling occasions). Physico-chemical parameters were determined based on Standard Methods (APHA, 1998): chemical oxygen demand (COD), biochemical oxygen demand $\left(\mathrm{BOD}_{5}\right)$, total suspended solids (TSS), total dissolved solids (TDS), ammonium $\left(\mathrm{NH}_{4}^{+}\right)$, total Kjeldahl nitrogen (TKN) and total phosphorus (Total P). The analyses were made immediately after sample collection, otherwise were properly stored. Dissolved oxygen (DO), $\mathrm{pH}$, conductivity and temperature were registered with a WTW handheld multi-parameter instrument 340i at the inlet and outlet of CWA and CWS.

\subsection{Microbial counts}

Colony Forming Units (CFU) were determined based on the surface-plate counting procedure as described previously (Calheiros et al., 2009a). Briefly, two sets of three subsamples were pooled to form one composite sample (10 g) of plant roots and substrate (from a depth between 5 and $10 \mathrm{~cm}$ ) of each CW series (sampling points: CWA2, CWA3, CWS2 and CWS3), which were placed separately in sterile tubes with $10 \mathrm{ml}$ of saline solution $(0.85 \%, \mathrm{w} / \mathrm{v}, \mathrm{NaCl})$ and shaken on a vortex mixer for $1 \mathrm{~min}$ at room temperature. Serial dilutions were made in duplicate and $0.1 \mathrm{ml}$ of each dilution was spread onto Marine agar (MA) and Nutrient agar (NA) media (LABM, UK). Plates were incubated at $25^{\circ} \mathrm{C}$ for 4 days. The same procedure was followed for bacterial enumeration of the wastewater at the inlet and outlet of each CW.

\subsection{Isolation and identification of bacteria}

\subsubsection{Bacteria isolation and DNA extraction}

Different bacterial colonies were isolated based on size, morphology and color, from Marine agar (MA) and Nutrient agar (NA) media, using a streak-plate procedure, were purified by successive subculturing, and further preserved at $80^{\circ} \mathrm{C}$ in 
modified Luria-Bertani broth, supplemented with 15\% (v/v) glycerol. DNA was extracted from pure bacterial isolates, using the heat-shock extraction method. Colonies of pure bacterial isolates were added to $200 \mu \mathrm{L}$ of sterile ultrapure water, vortexed to homogenize and heated at $95^{\circ} \mathrm{C}$ for $10 \mathrm{~min}$. Samples were then put into ice for $5 \mathrm{~min}$ and vortexed. Finally, samples were centrifuged at maximum velocity for $5 \mathrm{~min}$ and the supernatant was transferred to a sterile Eppendorf and DNA stored at $-20^{\circ} \mathrm{C}$.

\subsubsection{DNA sequencing analysis}

Isolates were identified by $16 \mathrm{~S}$ rRNA sequencing analysis. 16S rRNA was amplified in a $50 \mu \mathrm{L}$ reaction mix containing: $2 \mu \mathrm{L}$ of DNA template, $5 \mu \mathrm{L}$ of $10 \mathrm{x}$ buffer (Promega, USA), $5 \mu \mathrm{L}$ of $2.0 \mathrm{mM} \mathrm{MgCl}_{2}, 1 \mu \mathrm{L}$ of $250 \mu \mathrm{M}$ dNTPs, $0.5 \mu \mathrm{L}$ of $100 \mathrm{mM}$ f 27 and r1492 primers, 2 U TAQ polymerase (Promega, USA) and $1.25 \mu \mathrm{L}$ of DMSO (Sigma). PCR thermocycling parameters were as defined by Rainey et al. (1996). PCR products were run on $1.5 \%$ agarose gel stained with $\mathrm{SYBR}^{\circledR}$ Safe (Invitrogen, UK) (100 V for $30 \mathrm{~min}$ ) and visualized under a blue light. 16S rRNA products were purified using a GE purification kit, according to manufactures' instructions (GE Healthcare, UK). Cloning of the amplicons into pGEM T-Easy vector (Promega) and cycle sequencing were performed at Macrogen Inc. (Seoul, Republic of Korea) by using universal bacterial 16S rRNA primers (f27, r1492) (Lane, 1991).

\subsubsection{Nucleotide sequence accession numbers}

The 16S rRNA gene sequences of bacterial isolates used in this study are deposited in GenBank under the accession numbers referred in Table 2.

\subsection{Denaturating gradient gel electrophoresis of total community DNA}

The genomic DNA of substrate and root samples retrieved from each CW series (sampling points: CWA2, CWA3, CWS2

Table 1 - Mean composition of the water at the inlet and outlet of the constructed wetlands (CW) series. CWA: CW planted with Arundo donax, CWS: CW planted with Sarcocornia sp.

\begin{tabular}{lccc} 
Parameters & \multicolumn{3}{c}{ CW sampling compartment } \\
\cline { 2 - 4 } & Inlet & $\begin{array}{c}\text { CWS }- \\
\text { outlet }\end{array}$ & $\begin{array}{c}\text { CWA - } \\
\text { outlet }\end{array}$ \\
\cline { 2 - 4 } pH & $7.90 \pm 0.10$ & $7.84 \pm 0.06$ & $7.63 \pm 0.11$ \\
Conductivity & $16.96 \pm 0.21$ & $16.05 \pm 0.24$ & $15.99 \pm 0.16$ \\
$\quad\left(\mathrm{mS} \mathrm{cm}^{-1}\right)$ & $19.3 \pm 1.0$ & $15.3 \pm 1.7$ & $15.3 \pm 1.7$ \\
Temp. $\left({ }^{\circ} \mathrm{C}\right)$ & $0.75 \pm 0.22$ & $1.17 \pm 0.08$ & $1.18 \pm 0.11$ \\
DO $\left(\mathrm{mg} \mathrm{L}^{-1}\right)$ & $218 \pm 28$ & $88 \pm 11$ & $84 \pm 11$ \\
COD $\left(\mathrm{mg} \mathrm{L}^{-1}\right)$ & $37 \pm 6$ & $12 \pm 2$ & $10 \pm 2$ \\
BOD $\left(\mathrm{mg} \mathrm{L}^{-1}\right)$ & $97 \pm 17$ & $36 \pm 4$ & $30 \pm 3$ \\
TSS $\left(\mathrm{mg} \mathrm{L}^{-1}\right)$ & $10853 \pm 132$ & $10268 \pm 156$ & $10231 \pm 105$ \\
TDS $\left(\mathrm{mg} \mathrm{L}^{-1}\right)$ & $11.4 \pm 0.9$ & $4.7 \pm 0.6$ & $4.2 \pm 0.7$ \\
TKN $\left(\mathrm{mg} \mathrm{L}^{-1}\right)$ & $4.5 \pm 1.9$ & $1.3 \pm 0.7$ & $1.2 \pm 0.6$ \\
NH ${ }_{4}^{+}\left(\mathrm{mg} \mathrm{L}^{-1}\right)$ & $0.80 \pm 0.26$ & $0.30 \pm 0.06$ & $0.28 \pm 0.05$ \\
Total P $\left(\mathrm{mg} \mathrm{L}^{-1}\right)$ & & & \\
\hline
\end{tabular}

The values are means \pm SE (standard error of the mean). and CWS3) was extracted using the Ultra Clean ${ }^{\mathrm{TM}}$ Soil DNA Isolation Kit (MO BIO Laboratories, Inc., USA), according to the manufacturer's protocol. PCR amplification of bacterial $16 \mathrm{~S}$ rRNA gene fragments was performed using primers 338F_GC and 518R, as described previously (Calheiros et al., 2009a). Nested PCR amplifications were performed using as template $1 \mu \mathrm{L}$ of the DNA amplicon obtained after the first amplification round and the same primers and conditions applied in the first PCR amplification.

DGGE analysis was performed on a DCode ${ }^{\text {TM }}$ Universal Mutation Detection System (Bio-Rad Laboratories, Hercules, California, USA). Samples containing approximately $800 \mathrm{ng}$ of nested-PCR amplicons were loaded onto $8 \%(\mathrm{w} / \mathrm{v})$ polyacrylamide gels (37.5:1, acrylamid/bis-acrylamide) in 1x TAE buffer using a denaturing gradient ranging from 40 to $60 \%$ (100\% denaturant solution contained $7 \mathrm{M}$ urea and 40\% (v/v) formamide). A standard marker was also included in all gels, to serve as an indicator of the quality of the analysis (GeneRuler ${ }^{\mathrm{TM}}$ DNA Ladder Mix, Fermentas). Electrophoresis conditions and image acquisition were as described previously (Calheiros et al., 2009a).

DGGE profiles, concerning the presence and intensity of the bands, were analyzed using GelCompar ${ }^{\circledR}$ II software (VERSION 4.6; Applied Maths, Sint-Martens-Latem, Belgium). Detected band patterns were transferred to an absence/presence matrix. Bandmatching position tolerance was set at $1 \%$, with an optimisation of $0.5 \%$. The binary matrix was transformed into a similarity matrix using the Bray-Curtis measure. Dendrograms were generated by unweighted pair group mean average (UPGMA) cluster analysis.

DGGE banding data were used to estimate diversity, $H$ (Shannon and Weaver, 1963) and equitability, E (Pielou, 1975) indexes.

\subsection{Data analysis}

Statistical analysis were performed using the software SPSS (SPSS Inc., Chicago, IL, USA; Version 12.0). When applicable, the data was analyzed through one-way analysis of variance (ANOVA) and Student's t-test. To detect the statistical significance of differences $(p<0.05)$ between means of observation, the Duncan test was performed. When applicable, values were presented as the mean \pm standard error.

\section{Results and discussion \\ 3.1. Wastewater characterization}

The presence of salt may constrain the type of plants used in a CW for wastewater treatment since excessive salinity contents within the plant root zone has a general deleterious effect on plant growth (Rhoades et al., 1992). The effect of salt on CW treatment performance has been scantily studied (Klomjek and Nitisoravut, 2005; Wu et al., 2008). In the present study, the wastewater entering the CW series contained high amounts of salt being thus classified as highly saline according to Rhoades et al. (1992). The plants A. donax and Sarcocornia sp. were resilient to the high salinity conditions of the industrial wastewater applied to the CW. Table 1 shows the 
Table 2 - Phylogenetic affiliation of bacterial strains isolated from the Arundo donax and Sarcocornia sp. CW series.

\begin{tabular}{|c|c|c|c|c|c|}
\hline $\begin{array}{l}\text { Isolation } \\
\text { medium }\end{array}$ & $\begin{array}{c}\text { NCBI } \\
\text { accession no. }\end{array}$ & $\begin{array}{l}\text { Phylogenetic } \\
\text { affiliation }\end{array}$ & $\begin{array}{l}\text { Closest relative } \\
\text { (accession no.) }\end{array}$ & $\begin{array}{l}\text { Similarity } \\
(\%)\end{array}$ & $\begin{array}{l}\text { Isolation } \\
\text { source }\end{array}$ \\
\hline NA-AR & GU930745 & Bacteroidetes & Algoriphagus yeomjeoni (AY699795) & 99 & Marine solar saltern \\
\hline NA-AR & GU930753 & Firmicutes & Bacillus subtilis (FJ263034) & 100 & Grasslands \\
\hline NA-AR & GU930757 & Bacteroidetes & Flavobacteriaceae bacterium (AM403225) & 95 & Marine aquaculture biofilter \\
\hline NA-AR & GU930755 & $\beta$-Proteobacteria & Burkholderia sp. (GQ176352) & 99 & Deep-ocean basalts \\
\hline NA-AR & GU930766 & Actinobacteria & Microbacterium pumilum (AB234027) & 99 & Soil \\
\hline NA-AR & GU930773 & $\gamma$-Proteobacteria & Pseudomonas geniculata (EU239476) & 100 & Endophytic bacteria \\
\hline NA-AR & GU930774 & $\gamma$-Proteobacteria & Pseudomonas guineae (AM491811) & 99 & Antarctic environment \\
\hline NA-AS & GU930756 & $\alpha$-Proteobacteria & Crabtreella saccharophila (AB238789) & 99 & Soil \\
\hline NA-AS & GU930764 & $\gamma$-Proteobacteria & Listonella anguillarum (AY963631) & 99 & Scophthalmus maximus L. \\
\hline NA-AS & GU930761 & Actinobacteria & Gordonia sp. (AB476396) & 98 & Sewage \\
\hline NA-AS & GU930775 & $\gamma$-Proteobacteria & $\begin{array}{l}\text { Pseudomonas pseudoalcaligenes } \\
\text { (EU440977) }\end{array}$ & 100 & Ocean deep sea water \\
\hline MA-AR & GU930783 & $\gamma$-Proteobacteria & Rheinheimera sp. (AM110966) & 99 & $\begin{array}{l}\text { Deep sea sediment of } \\
\text { the east Pacific }\end{array}$ \\
\hline MA-AS & GU930746 & Actinobacteria & Arthrobacter sp. (AM900502) & 99 & Paint \\
\hline MA-AS & GU930747 & Firmicutes & Bacillus cereus (GQ855296) & 99 & Silicon layer \\
\hline MA-AS & GU930748 & Firmicutes & Bacillus megaterium (GQ479946) & 100 & Wool-degrading isolates \\
\hline MA-AS & GU930749 & Firmicutes & Bacillus pumilus (EU855196) & 99 & Soy paste \\
\hline MA-AS & GU930758 & Bacteroidetes & Flavobacteriaceae bacterium (DQ660394) & 99 & Nd \\
\hline MA-AS & GU930760 & Actinobacteria & Gordonia sp. (FJ411166) & 98 & $\begin{array}{l}\text { PAHs wastewater } \\
\text { treatment plant }\end{array}$ \\
\hline MA-AS & GU930762 & $\gamma$-Proteobacteria & Halomonas sp. (DQ985041) & 99 & Marine environments \\
\hline MA-AS & GU930763 & $\gamma$-Proteobacteria & Halomonas sp. (GU549493) & 99 & $\mathrm{Nd}$ \\
\hline MA-AS & GU930750 & Firmicutes & Bacillus sp. (GQ199750) & 100 & Organic nematicidal volatiles \\
\hline MA-AS & GU930765 & $\gamma$-Proteobacteria & Listonella anguillarum (GQ409862) & 99 & Plecoglossus altivelis \\
\hline MA-AS & GU930767 & Actinobacteria & Micrococcus luteus (AB539975) & 99 & $\mathrm{Nd}$ \\
\hline MA-AS & GU930769 & $\alpha$-Proteobacteria & Paracoccus sp. (AM231059) & 98 & Denitrifier environment \\
\hline MA-AS & GU930771 & $\gamma$-Proteobacteria & Pseudoalteromonas sp. (AF172989) & 99 & Marine alga Ulva lactuca \\
\hline MA-AS & GU930779 & $\gamma$-Proteobacteria & Pseudomonas sp. (FN429930) & 98 & $\begin{array}{l}\text { Vegetable and animal } \\
\text { waste compost }\end{array}$ \\
\hline MA-AS & GU930780 & $\gamma$-Proteobacteria & Pseudomonas sp. (DQ319039) & 100 & $\begin{array}{l}\text { Coastal marine waters of } \\
\text { Jiaozhou Bay, China }\end{array}$ \\
\hline MA-AS & GU930781 & $\gamma$-Proteobacteria & Pseudomonas stutzeri (AJ312173) & 99 & Marine sediment and soils \\
\hline MA-AS & GU930782 & $\gamma$-Proteobacteria & Pseudomonas stutzeri (GQ407271) & 100 & Drinking water \\
\hline MA-AS & GU930789 & Firmicutes & Staphylococcus epidermidis (EF522128) & 99 & $\begin{array}{l}\text { Sugarcane plants } \\
\text { grown in Cuba }\end{array}$ \\
\hline MA-AS & GU930791 & Firmicutes & Staphylococcus pasteuri (AF041361) & 100 & Meat \\
\hline MA-AS & GU930792 & Firmicutes & Staphylococcus sp. (FJ380987) & 100 & Tobacco whitefly Bemisia tabaci \\
\hline MA-AS & GU930794 & Firmicutes & Staphylococcus sp. (GQ354273) & 100 & Estuarine environment \\
\hline NA-SR & GU930751 & Firmicutes & Bacillus sp. (GU120635) & 99 & Soil \\
\hline NA-SR & GU930752 & Firmicutes & Bacillus sp. (GU048940) & 100 & Contaminated sites \\
\hline NA-SR & GU930770 & $\beta$-Proteobacteria & Planococcus sp. (EF471920) & 99 & Halophilic bacteria \\
\hline NA-SR & GU930778 & $\gamma$-Proteobacteria & Pseudomonas sp. (AM989281) & 99 & Water blooms \\
\hline NA-SR & GU930784 & $\gamma$-Proteobacteria & Rheinheimera sp. (DQ985066) & 98 & Marine environments \\
\hline NA-SR & GU930785 & $\gamma$-Proteobacteria & Rheinheimera sp. (AM690025) & 99 & $\begin{array}{l}\text { Soil samples from the } \\
\text { western Himalayas }\end{array}$ \\
\hline NA-SS & GU930759 & Bacteroidetes & Flavobacterium sp. (AM934641) & 98 & Rivulet water and tufa biofilm \\
\hline NA-SS & GU930788 & Firmicutes & Staphylococcus epidermidis (GU003866) & 100 & $\begin{array}{l}\text { Wastewater influent, } \\
\text { activated sludge, sequencing } \\
\text { batch reactor }\end{array}$ \\
\hline NA-SS & GU930777 & $\gamma$-Proteobacteria & Pseudomonas sp. (EU841539) & 99 & $\begin{array}{l}\text { 2-carboxamido-piperazine } \\
\text { lytic bacteria }\end{array}$ \\
\hline NA-SS & GU930786 & $\gamma$-Proteobacteria & Shewanella putrefacien (U91552) & 98 & $\mathrm{Nd}$ \\
\hline MA-SR & GU930768 & $\alpha$-Proteobacteria & Paracoccus sp. (AJ313424) & 99 & Antarctic environment \\
\hline MA-SR & GU930772 & $\gamma$-Proteobacteria & Pseudomonas anguilliseptica (NR_029319) & 99 & $\mathrm{Nd}$ \\
\hline MA-SR & GU930790 & Firmicutes & Staphylococcus epidermidis (FJ195008) & 100 & Paddy fields \\
\hline MA-SR & GU930793 & Firmicutes & Staphylococcus sp. (AB461081) & 100 & $\mathrm{Nd}$ \\
\hline MA-SS & GU930754 & Firmicutes & Bacillus thuringiensis (EU124380) & 100 & $\mathrm{Nd}$ \\
\hline MA-SS & GU930776 & $\gamma$-Proteobacteria & Pseudomonas sp. (EU167990) & 99 & Shrimp rearing tanks \\
\hline MA-SS & GU930787 & $\alpha$-Proteobacteria & Sphingomonas sp. (AB255386) & 99 & $\mathrm{Nd}$ \\
\hline
\end{tabular}

In the column designated as "Isolation medium" is presented: the culture media from where the isolates were retrieved (NA-Nutrient Agar or MA-Marine Agar), followed by the constructed wetland series from where they were isolated (A-A. donax CW series or S-Sarcocornia sp. CW series) and then the sample origin (R: root or S: substrate) from which each sample was collected. Nd - Not determined. 
mean composition of the wastewater at the inlet and outlet of each CW series. The presented data corresponds to the sampling periods made for microbiological analysis. Samples were taken when the series operated with a $4 \mathrm{~m}^{3} \mathrm{~d}^{-1}$ flow and with a $10 \mathrm{~m}^{3} \mathrm{~d}^{-1}$, from January to June 2008. The $\mathrm{pH}$ and conductivity were similar between the inlet and outlet of each CW series. DO was in general higher at the outlet than at the inlet, varying between 0.97 and $1.4 \mathrm{mg} \mathrm{L}^{-1}$ and 0.31 and $1.29 \mathrm{mg} \mathrm{L}^{-1}$, respectively. The $\mathrm{COD}$ and $\mathrm{BOD}_{5}$ removal efficiency of the CW series varied between 58 and $67 \%$ and 60 and $77 \%$, respectively. The organic loading ranged between 16 and $50 \mathrm{~g} \mathrm{COD} \mathrm{m}^{-2} \mathrm{~d}^{-1}$ and an organic removal up to $33 \mathrm{~g} \mathrm{COD}$ $\mathrm{m}^{-2} \mathrm{~d}^{-1}$ was achieved. Removal of TSS varied between 52 and $82 \%$. TDS did not face high oscillations between the inlet and outlet. The TKN and $\mathrm{NH}_{4}^{+}$removal varied between 51 and $79 \%$ and 60 and $86 \%$ respectively. Total phosphorus concentration was low being similar for the inlet and outlet of both series. The reduction achieved for $\mathrm{BOD}_{5}, \mathrm{COD}$, TSS, TKN and $\mathrm{NH}_{4}^{+}$is related to the treatment mechanisms occurring in $\mathrm{CW}$ that comprise several physical, chemical, and biological processes. Daniels (2007) reported reductions in BOD (92\%) and COD $(90 \%)$ from a CW receiving highly concentrated tannery effluents (10,000 $\left.\mathrm{mg} \mathrm{L}^{-1} \mathrm{TDS}\right)$ with concentrations of $800 \mathrm{mg} \mathrm{L}^{-1}$ in BOD and $2500 \mathrm{mg} \mathrm{L}^{-1}$ in COD, while Calheiros et al. (2009b) reported reductions up to $88 \%$ of $\mathrm{BOD}_{5}$ (from an inlet of $420-1000 \mathrm{mg} \mathrm{L}^{-1}$ ) and $92 \%$ of COD (from an inlet of $808-2449 \mathrm{mg} \mathrm{L}^{-1}$ and organic loadings ranging between 24 and $193 \mathrm{~g} \mathrm{COD} \mathrm{m}^{-2} \mathrm{~d}^{-1}$ ). Since in the present study we were dealing with a wastewater polishing process, the organic loadings were much lower than those reported in literature concerning secondary treatment of tannery effluents.

\subsection{Bacterial enumeration and isolation}

Regarding the microbial diversity of CW wastewater treatment systems operating with a high salt content, scarce information is available.

At the inlet of the CW series, CWA and CWS, the average bacterial counts, in NA medium, were of $4.14 \times 10^{5} \pm 5.63 \times 10^{4} \mathrm{CFU} \mathrm{ml}{ }^{-1}$. For the outlet of the series counts were lower, in average $1.06 \times 10^{5} \pm 1.56 \times 10^{4} \mathrm{CFU} \mathrm{ml}{ }^{-1}$ for CWA and $1.03 \times 10^{5} \pm 1.43 \times 10^{4} \mathrm{CFU} \mathrm{ml}{ }^{-1}$ for CWS. ANOVA one-way was performed to compare the counts in terms of $\mathrm{CFU} \mathrm{ml} \mathrm{m}^{-1}$ and significant differences between the wastewater inlet and the outlet of both CW were found.

Average bacterial counts obtained in NA medium, from the root and substrate samples of each system, are shown in Fig. 2. Samples were taken in different months (January, February, March and June of 2008) from CWA (A. donax series), at CWA2 and CWA3 compartments, and CWS (Sarcocornia sp. series), at CWS2 and CWS3 compartments. The CFU varied between $1.94 \times 10^{7}$ and $8.46 \times 10^{8} \mathrm{CFU} \mathrm{g}^{-1}$ for CWA and between $1.72 \times 10^{7}$ and $1.01 \times 10^{8} \mathrm{CFU} \mathrm{g}^{-1}$ for CWS series. When one-way ANOVA was applied to compare the counts from the root and substrate of each CW series independently, no significant differences were observed. When comparing the counts from each series, the CWA presented significantly higher values when compared to CWS series, through Student t-test application. Bacterial counts from the root and substrate samples of each system were also undertaken in MA medium

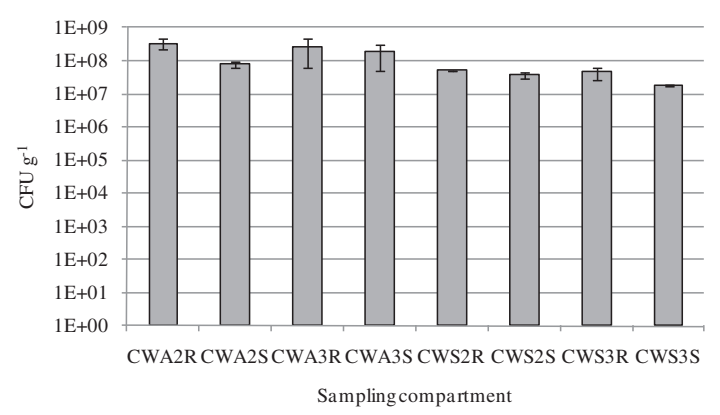

Fig. 2 - Bacterial enumeration analyzed by plate counts, in nutrient agar medium, expressed in $\mathrm{CFU}^{-1}$ for substrate (S) and plant roots (R) of constructed wetlands (CW) series. Average values correspond to samples taken in different months (January, February, March and June of 2008), from CWA (Arundo donax series) at the compartments CWA2 and CWA3, and CWS (Sarcocornia sp. series) at the compartments CWS2 and CWS3. Dispersion bars represent standard error of the mean.

in one sampling occasion. Average bacterial counts for CWA were $9.54 \times 10^{7} \mathrm{CFU} \mathrm{g}^{-1}\left(5.75 \times 10^{6}-1.75 \times 10^{8} \mathrm{CFU} \mathrm{g}^{-1}\right)$ and for CWS were $2.20 \times 10^{8} \mathrm{CFU} \mathrm{g}^{-1}\left(5.97 \times 10^{6}-3.95 \times 10^{8} \mathrm{CFU} \mathrm{g}^{-1}\right)$. Bacterial counts found for root and substrate samples were in the range reported in other studies related to CW for tannery wastewater treatment (Calheiros et al., 2009a). The fact that there were no significant differences on bacterial numbers between the substrate and the roots in the series (CWA and CWS) may be attributed to the diffuse propagation of each plant species. Although the CWA series had significant higher counts than CWS, this can be explained due to the highly developed root system of A. donax when compared to the Sarcocornia sp. The root system development was observed whenever root sampling was undertaken. Different plant species may have influence on the number of bacteria on roots; the study of Vymazal et al. (2001) reported that there were significantly higher bacterial counts on Phragmites australis roots when compared to the roots Phalaries arundinacea in a CW receiving municipal sewage.

Fifty bacterial isolates were retrieved from media NA and MA, from plant roots and substrate. Most of the isolates (33) came from the A. donax CW, 22 culturable in MA and 11 in NA. From the CW planted with Sarcocornia sp., other 17 isolates were identified, 10 retrieved from NA medium and 7 from MA medium. These isolates were characterized through the determination of the nucleotide sequence of the 16S rRNA gene. Accordingly to BLAST results (Table 2), 20 strains were affiliated with $\gamma$-Proteobacteria (13 from CWA and 7 from CWS), 15 with Firmicutes (9 from CWA and 6 from CWS), 5 with Actinobacteria (5 from CWA), 4 with Bacteroidetes (3 from CWA and 1 from CWS), 4 with $\alpha$-Proteobacteria (2 from CWA and 2 from CWS) and 2 with $\beta$-Proteobacteria ( 1 from CWA and 1 from CWS). Many of them shared $100 \%$ similarity with sequences deposited in GenBank and were closely related to environmental isolates reported from sources such as marine environments, sediments, soils and biological wastewater treatment systems. Studies on the microbial diversity from 


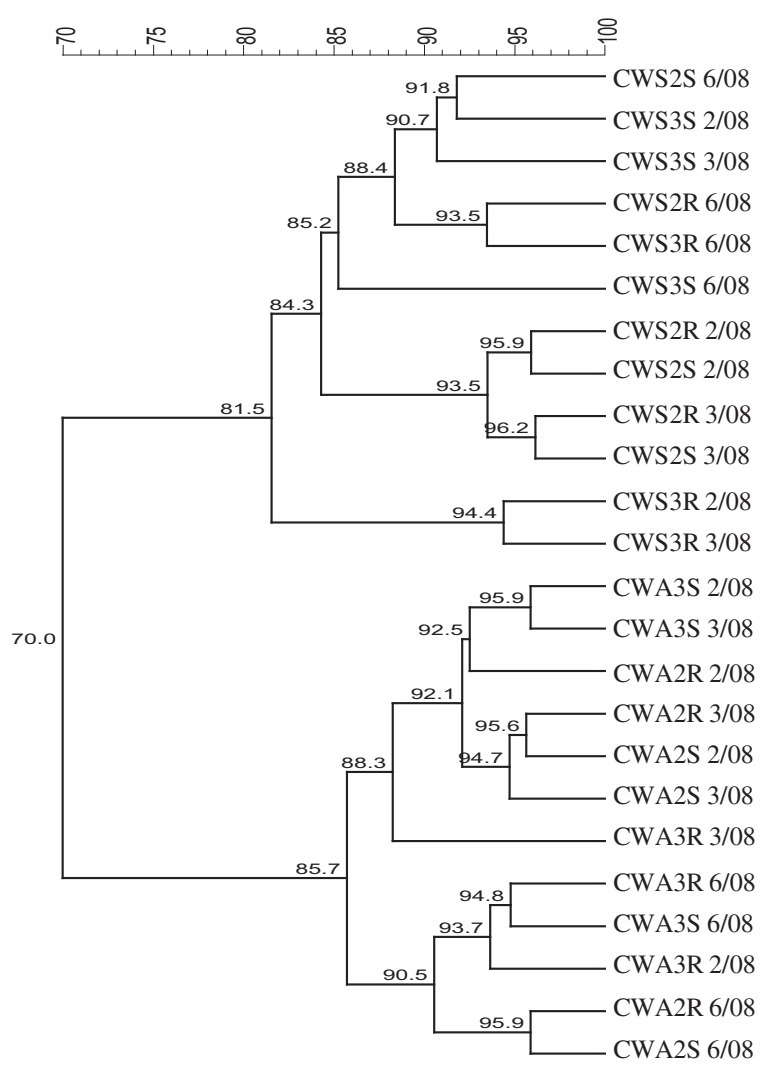

Fig. 3 - Cluster analysis of DGGE patterns of root (R) and substrate (S) samples taken in different months, from CWA at the compartments CWA2 and CWA3 (Arundo donax series), and CWS, at the compartments CWS2 and CWS3 (Sarcocornia sp. series). Similarities were calculated using the Bray-Curtis measure.

CW treating tannery wastewater with high organic load (Calheiros et al., 2009a) and from hypersaline tannery wastewater (Lefebvre et al., 2006) also reported the presence of bacterial isolates belonging to the $\alpha$ - and $\gamma$-Proteobacteria, Firmicutes, Actinobacteria and Bacteroidetes groups. Aguilar et al. (2008) performed a study on the characterization of sulphuroxidizing bacteria in wetland treating tannery wastewater and reported bacterial isolates with similarities to $\alpha-, \beta$ - and $\gamma$-Proteobacteria subgroups and affiliated with Actinobacter sp. Franco et al. (2005), based on enrichment cultures with soil collected nearby a tannery wastewater discharge site, isolated bacteria affiliated to $\gamma$-Proteobacteria able to degrade polyphenols (substance used in tannery processes).

\subsection{Molecular analysis of bacterial communities of the $\mathrm{CW}$ series}

Little is known regarding the microbial diversity of CW treating hypersaline wastewater. In this study, different microbial profiles were found between the two series of CW. In order to assess the relatedness of phylogenetic profiles corresponding to the communities of each CW series, at each sampling time and location (substrate and root), a cluster analysis was performed. The samples from each series clustered together showing
Table 3 - Shannon diversity $(H)$ and Equitability $(E)$ indexes, calculated for the constructed wetlands (CW) series. CWA: CW planted with Arundo donax (compartments: CWA2 and CWA3) and CWS: CW planted with Sarcocornia sp. (compartments: CWS2 and CWS3).

\begin{tabular}{|c|c|c|c|c|c|c|}
\hline \multirow[t]{2}{*}{ Samples* } & \multicolumn{2}{|c|}{$\mathrm{Feb} / 08^{\Delta}$} & \multicolumn{2}{|c|}{ March/08 } & \multicolumn{2}{|c|}{ June/08 ${ }^{\Delta}$} \\
\hline & $\mathrm{H}$ & E & $\mathrm{H}$ & $E$ & $\mathrm{H}$ & $E$ \\
\hline CWA2-R & 1.14 & 0.99 & 1.17 & 1.00 & 1.19 & 0.99 \\
\hline CWA2-S & 1.11 & 0.99 & 1.19 & 0.99 & 1.07 & 0.99 \\
\hline CWA3-R & 1.04 & 1.00 & 1.22 & 0.99 & 1.24 & 1.08 \\
\hline CWA3-S & 1.16 & 0.98 & 1.09 & 0.95 & 0.94 & 0.84 \\
\hline CWS2-R & 0.94 & 0.99 & 1.25 & 0.99 & 1.07 & 0.99 \\
\hline CWS2-S & 1.14 & 1.00 & 1.16 & 0.99 & 1.21 & 0.98 \\
\hline CWS3-R & 1.07 & 1.00 & 0.94 & 0.99 & 0.94 & 0.85 \\
\hline CWS3-S & 1.10 & 0.99 & 1.20 & 1.00 & 0.99 & 0.84 \\
\hline
\end{tabular}

* The sample origin (R: root or S: substrate) and the respective CW compartment (CWA2, CWA3, CWS2 and CWS3) of the samples are identified. ${ }^{\Delta}$ The month and year of sample collection is presented.

a similarity of $70 \%$ between the series planted with different species (Fig. 3). The type of plant within each CW series had an evident effect on the bacterial communities whereas the sampling time (different months) did not. Caravaca et al. (2005) also suggested that the plant type has influence on the rhizosphere soil microbiological and biochemical properties, when studying eight halophytes in a salt marsh.

Some samples from CWS and from CWA clustered according to the location of collection (substrate and root), expressing, in general, similarities higher than $88 \%$. There was no clear relation between the sample collection time and the spatial factor (series compartment CWA2-3 or CWS2-3). Also, the difference between the bacterial assemblages of each series is evident, reinforcing the effect of type of plant (A. donax and Sarcocornia) in the bacterial community. This is in agreement with Calheiros et al. (2009a) that claimed an evident effect of the type of plant used in the CW in the bacterial communities established. Zhang et al. (2010) when studying the effects of plant diversity on microbial biomass and community metabolic profiles in a CW for domestic wastewater treatment suggested that changes in the structure of microbial community strongly depends on the presence or absence of plants.

The diversity and equitability indexes were calculated based on DGGE profiles (Table 3). The Shannon's diversity index $(H)$ was in average of $1.13 \pm 0.02$ for CWA and $1.08 \pm 0.03$ for CWS. The equitability index $(E)$ was in average of $0.98 \pm 0.02$ for CWA and $0.97 \pm 0.02$ for CWS. Corroborating the present study, Calheiros et al. (2009a) reported, in general, $\mathrm{H}$ values above 1.0, for CW systems with high efficiency of organic removal from wastewater. The distinctive assemblages corresponding to each series may be influenced by the morphology and development of plant species.

\section{Conclusions}

In this study the microbial dynamics of root and substrate from two horizontal subsurface flow CW series planted with different species, operating for polishing treatment of highly 
saline tannery wastewater, was investigated. The main conclusions of this investigation are summarized as follows.

- The high salt content in the wastewater did not jeopardize the removal efficiency of organic matter in CW.

- The clustering analysis suggested that a diverse and distinct bacterial community inhabits each CW series.

- The type of plant seems to have a major effect on the established bacterial communities.

- CW with different plants performed well in terms of organic matter removal, which may be due to the high bacterial diversity found within the systems.

\section{Acknowledgements}

This work was supported by the AdI, PRIME - IDEIA Programme, through the Project no. 70/00324 - Planticurt. The authors acknowledge the support of Inducol, S.A. Cristina S.C. Calheiros and C. Pires wish to thank the research grants from Fundação para a Ciência e Tecnologia (FCT), Portugal (SFRH/ BPD/63204/2009 and SFRH/BD/25493/2005).

\section{R E F E R E N C E S}

APHA, 1998. Standard Methods for the Examination of water and wastewater, twentieth ed. American Public Health Association/American Water Works Association/Water Environment Federation, WashingtonDC, USA.

Aguilar, J.R.P., Cabriales, J.J.P., Vega, M.M., 2008. Identification and characterization of sulfur-oxidizing bacteria in an artificial wetland that treats wastewater from a tannery. International Journal of Phytoremediation 10, 359-370.

Calheiros, C.S.C., Rangel, A.O.S.S., Castro, P.M.L., 2007 Constructed wetland systems vegetated with different plants applied to the treatment of tannery wastewater. Water Research 41 (8), 1790-1798.

Calheiros, C.S.C., Duque, A.F., Moura, A., Henriques, I.S., Correia, A., Rangel, A.O.S.S., Castro, P.M.L., 2009a. Changes in the bacterial community structure in two-stage constructed wetlands with different plants for industrial wastewater treatment. Bioresource Technology 100 (13), 3228-3235.

Calheiros, C.S.C., Rangel, A.O.S.S., Castro, P.M.L., 2009b. Treatment of industrial wastewater with two-stage constructed wetlands planted with Typha latifolia and Phragmites australis. Bioresource Technology 100 (13), 3205-3213.

Caravaca, F., Alguacil, M.M., Torres, P., Roldán, A., 2005. Plant type mediates rhizospheric microbial activities and soil aggregation in a semiarid Mediterranean salt marsh. Geoderma 124, 375-382.

Collins, B., McArthur, J.V., Sharitz, R.R., 2004. Plant effects on microbial assemblages and remediation of acidic coal pile runoff in mesocosm treatment wetlands. Ecological Engineering 23, 107-115.
Daniels, R.P., 2008. Giving nature a chance. S\&V African Leather 2 (5), 17-21.

Daniels, R.P., 2007. Tannery effluent and reedbeds: working with nature. Jalca 102, 248-253.

EC., 2003. Integrated Pollution Prevention and Control (IPPC), Reference Document on Best Available Techniques for the Tanning of Hides and Skins. BAT Reference Document (BREF). European Commission. European IPPC Bureau, Seville. Spain.

Franco, A.R., Calheiros, C.S.C., Pacheco, C.C., De Marco, P., Manaia, C.M., Castro, P.M.L., 2005. Isolation and Characterization of polyphenol degrading bacteria from a tannery discharge place. Microbial Ecology 50, 550-556.

Faulwetter, J.L., Gagnon, V., Sundberg, C., Chazarenc, F., Burr, M.D., Brisson, J., Campera, A.K., Stein, O.R., 2009. Microbial processes influencing performance of treatment wetlands: a review. Ecological Engineering 35, 987-1004.

Gagnon, V., Chazarenc, F., Comeau, Y., Brisson, J., 2007. Influence of macrophyte species on microbial density and activity in constructed wetlands. Water Science and Technology 56 (3), 249-254.

Kaseva, M.E., Mbuligwe, S.E., 2010. Potential of constructed wetland systems for treating tannery industrial wastewater. Water Science and Technology 61 (4), 1043-1052.

Klomjek, P., Nitisoravut, S., 2005. Constructed treatment wetland: a study of eight plant species under saline conditions. Chemosphere 58, 585-593.

Lane, D.J., 1991. 16S/23S rRNA sequencing. In: Stackebrandt, E., Goodfellow, M. (Eds.), Nucleic Acid Techniques in Bacterial Systematics. John Wiley and Sons Ltd, West Sussex, England.

Lefebvre, O., Vasudevan, N., Thanasekaran, K., Moletta, R., Godon, J.J., 2006. Microbial diversity in hypersaline wastewater: the example of tanneries. Extremophiles 10 (6), 505-513.

Pielou, E.C., 1975. Ecological Diversity. Wiley, New York.

Rainey, F.A., Ward-Rainey, N., Kroppenstedt, R.M., Stackebrandt, E., 1996. The genus Nocardiopsis represents a phylogenetically coherent taxon and a distinct actinomycete lineage: proposal of Nocardiopsaceae fam. nov. International Journal of Systematic Bacteriology 46, 1088-1092.

Rhoades, J.D., Kandiah, A., Mashali, A.M., 1992. The Use of Saline Waters for Crop Production - FAO. Food and Agriculture Organization of the United Nations.Rome, Italy.

Shannon, C.E., Weaver, W., 1963. The Mathematical Theory of Communication. University of Illinois Press, Urbana, IL.

Stottmeister, U., Wießner, A., Kuschk, P., Kappelmeyer, U., Kästner, M., Bederski, O., Müller, R.A., Moormann, H., 2003. Effects of plants and microorganisms in constructed wetlands for wastewater treatment. Biotechnology Advances 22, 93-117.

Truu, M., Juhanson, J., Truu, J., 2009. Microbial biomass, activity and community composition in constructed wetlands. Science of the Total Environment 407 (13), 3958-3971.

Vymazal, J., Balcarová, J., Dousǒvá, H., 2001. Bacterial dynamics in the sub-surface constructed wetland. Water Science and Technology 44 (11/12), 207-209.

Wu, Y., Tam, N.F.Y., Wong, M.H., 2008. Effects of salinity on treatment of municipal wastewater by constructed mangrove wetland microcosms. Marine Pollution Bulletin 57, 727-734

Zhang, C.-B., Wang, J., Liu, W.-L., Zhu, S.-X., Ge, H.-L., Chang, S.X., Chang, J., Ge, Y., 2010. Effects of plant diversity on microbial biomass and community metabolic profiles in a full-scale constructed wetland. Ecological Engineering 36 (1), 62-68. 